\title{
LEARNING THEORIES IN INSTRUCTIONAL MULTIMEDIA FOR ENGLISH LEARNING
}

\author{
Rizki Farani \\ Islamic University of Indonesia
}

\begin{abstract}
Learning theory is the concept of human learning. This concept is one of the important components in instructional for learning, especially English learning. English subject becomes one of important subjects for students but learning English needs specific strategy since it is not our vernacular. Considering human learning process in English learning is expected to increase students' motivation to understand English better.

Nowadays, the application of learning theories in English learning has appeared in several learning methods and media. One of popular media today is instructional multimedia by using computer. There are many educators who design English material in certain computer software or games. It is still possible to apply learning theories in instructional multimedia program since multimedia provides complete learning by using text, picture, sound, video and animation. Multimedia program can adapt students' differences in learning. It is a good potential of collaborating learning process and technology to learn English better.

The program will help students to master the whole English language competence (listening, speaking, reading and writing).

This paper will discuss the types of learning theory that can be used in instructional multimedia to learn English. This paper also provides several examples of instructional multimedia product that contain learning theories application.
\end{abstract}

Key Words: Learning theories, Instructional multimedia, English learning

\section{INTRODUCTION}

Learning theory is basic theory about how humans learn. It leads to the development of new knowledge, skills or attitudes as an individual with information and the environment (Smaldino et.al, 2005: 6). Learning theory is also 
assumption references about learning process, proved through research and experience (Warsita, 2008: 61). It focuses on several aspects such as how students learn or psychological condition. There are four general perspectives on learning theory, for instance; behaviorist perspective, cognitive perspective, constructivist perspective and social-psychological perspective (Smaldino et.al, 2005: 6-7). These perspectives are one of the basic considerations in designing instructional material for learning, especially English learning.

English learning has become important skill for students in all level of education. There are many methods, invented by teachers, lecturer, educators or instructors, to support effective English learning. Nowadays, one of the popular methods is designing English learning is using multimedia program by using computer to make English material presentations such as Listening, Speaking, Reading and Writing. Multimedia computer program gives positive effects in visualizing English concept by combining text, picture, sound, video or animation. This program helps learner to comprehend all English skills in one presentation.

However, designing effective multimedia presentation and considering the process of human learning at the same time is not easy. It requires methodological steps in analyzing human learning, English material and multimedia program itself. This paper will discuss about how to apply learning theories in instructional multimedia program for English learning.

\section{LITERATURE REVIEW}

\section{Learning Theories}

There are four general learning theories in education field. The first theory is behaviorist perspective. This perspective views that behavior can be shaped by reinforcing or rewarding to achieve the desired responses to the environment (Pavlov in Smaldino et.al, 2005: 6). This theory emphasize on changes in behavior or performance. In the other words, learning output is more important than learning process. The characters of behaviorist learning process are (Hartley\&Davies, 1978 in Warsita, 2008:67):

a. Students' participation is important in learning process.

b. Learning material is designed in sequence to help students understand the content easily.

c. Students' responses should be followed by feedbacks and reinforcement. 
The second theory is cognitive perspective that focuses on how people receive process and manipulate information (Piaget in Smaldino et.al, 2005: 6). This perspective also concerns about how people think, solve problems and making decisions. Thus, the principles of cognitive theory are understanding ideas or concepts and finding the connection among them (Warsita, 2008:69). The third theory is constructivist theory. It is a movement that extends beyond the beliefs of the cognitive. It considers the engagement of students in meaningful experiences as the essence of experiential learning (Smaldino et.al, 2005: 6). In learning process, this theory encourages students to do a group discussion, find solution for problems and integrate some new information (Nurhadi et.al, 2004 in Warsita, 2008:137).

The last perspective, that is social-psychological perspective looks at the effect of social organization of the classroom on learning, for instance: group structure in the classroom, authority structure of the class and reward structure. The example of social-psychological perspective is the research conducted by Robert Slavin that says cooperative learning is both more effective and more socially beneficial than competitive and individualist learning (Slavin in Smaldino et.al, 2005:7).

The learning perspectives above create different approaches in designing instruction for learning based on the focus of each perspective. However, successful instructional practices have features that are supported by virtually all the various perspectives, such as active participation, practice, individual differences, feedback, realistic contexts and social interaction. These features are accommodated by instructional media and technologies for learning that can help provide a learning atmosphere in which students actively participate (Smaldino et.al, 2005: 4-9).

\section{Learning Theories in Instructional Multimedia}

The application of technology in learning leads us to the application of multimedia. Multimedia is the presentation of material using both words and pictures (Mayer, 2007: 2). In learning process, presenting material in multimedia product gives opportunity for learners to process the information. It means multimedia product gives interactive channel for learners to comprehend the material in various aspects such as text, images, video, audio and animation. 
The advantages of using multimedia in learning are provide various information sources and instructional methods, stimulate more closely to the conditions of real-world learning and a world of multisensory all at once experience. Multimedia also addresses different learning styles such as auditory learners, visual learners or tactile learners. By using multimedia, students can choose the most meaningful sensory mode for them (Smaldino et.al, 2005: 142).

The aspect of learning theories can be found in several multimedia products, for example computer-based instruction and web-based courses. Behaviorist theory is basic concept in designing computer-based activity or webbased task because it leads student to a series of instructional steps to a desired level of performance (Smaldino, 2005: 8). When students study English by using computer-based instruction or multimedia program, they should follow certain instruction such as open computer software or files, login to a link in a website or register in social networks. If they do not follow the steps, they cannot access the material.

Furthermore, other theories also play significant roles as a bridge to enhance students' mastery by using multimedia. Cognitive theory usually focuses on choosing appropriate material for students based on students' interest and demand. Two passages below are two examples of specific reading passage for students in Islamic institution.

Passage 1

Our national history shows that non formal education such as Islamic boarding school (Pesantren) contributes a great movement to our nation in preparing community leaders and propagating religion. This institution educates people to be volunteers, teachers, propagators, informal leaders or social workers. Usually, these people dedicate themselves at religious institutions and nongovernmental organizations. Their devotion, dedication and commitment have been taken for granted by the government. (Quoted from: Muhibbin Syah. Islamic English. 2005:89).

Passage 2

One billion people from a vast range of races, nationalities and cultures across the globe, from the southern Philippines to Nigeria are united by their common Islamic faith. About $18 \%$ live in the Arab world. The world's largest Muslim community is in Indonesia. Substantial parts of Asia and most of Africa are 
Muslim, while significant minorities are to be found in the Soviet Union, China, North and South America and Europe (Quoted from: Azhar Arsyad. Step by Step Readings in English for IAIN Students. 2006: 123).

Passage 3

Islam views a woman, whether single or married, as an individual in her own right, with the right to own and dispose of her property and earnings. A marriage dowry is given by the groom to the bride for her own personal use, and she keeps her own family name rather than adopting her husband's. Both men and women are expected to dress in a way which is modest and dignified. The traditions of female dress found in some Muslim countries are often the expression of local customs. (Quoted from: Arsyad, Azhar. Step by Step Readings in English for IAIN Students, 2006: 125).

Passage 1, 2 and 3 are selected materials about Islam. The purpose of choosing Islamic passage is to increase students' motivation in learning English with familiar content. They can read, analyze and widen the passage to discuss Islamic issues.

In addition, constructivist and social-psychological perspective roles in building students' knowledge and encourage team work. The application is usually shown in the method of instruction. One of the examples is the development of Contextual Teaching and Learning (CTL). CTL is learning concept that helps teacher to connect material to the real world and encourage students to analyze the connection and apply the skills in real condition. In this case, learning strategies is more important that learning achievement. The learning strategies usually consists of 7 steps such as constructivism, inquiry, questioning, learning community, modeling, reflection and authentic assessment (Nurhadi et.al, 2004 in Warsita, 2008:137).

In computer program, constructivist theory is usually shown in educational simulation. Educational simulations are structured environments, abstracted from some specific real-life activities, with stated levels and goals. This simulation allows participant to practice real world skills with appropriate feedback without affecting real process or people, for example educational simulation games about showing direction (Aldrich, 2009:7-8). Learner will learn the vocabulary and the expression to show direction from one place to another place by clicking a button to move people around. By doing this activity, student will learn how to use the 
vocabularies and the expression in "real-life" conversation. Specifically, educational simulation offers several positive effects such as create a sense of presence, access diverse real-world communities, increase students' engagement with the material, provide "real-lab" for students, increase the depth of knowledge and present critical content.

The examples above show that multimedia program in a computer support the application of learning theories, especially in English learning. In the other word, high technology still can accommodate students' differences in learning process.

\section{Learning Theories and Multimedia for English Learning}

In English learning, the material focuses on mastering four skills such as listening, speaking, reading and writing. The output of the instructions depends on the goal of learning which are teaching English as a second language or English as a foreign language. English as a second language focuses on English as studied by people who speak other language but live in places where English is the first language. Meanwhile English as foreign language is English as studied by people who live in places where English is not the first language (Gebhard, 2005: 2). Based on this concept, English learning in Indonesia states English as a foreign language. Therefore, the objective of the instruction is to help students comprehend English.

Multimedia roles as a component in instructional design to reproduce or recognize presented material and present material in novel situation (Mayer, 2007: 16). It means that multimedia presents English material certain visualization from abstract concept. The combination of English material character and multimedia presentation is one format of learning theories application. To gain more understanding about learning theory integration in English learning, analyze the multimedia presentation below. 


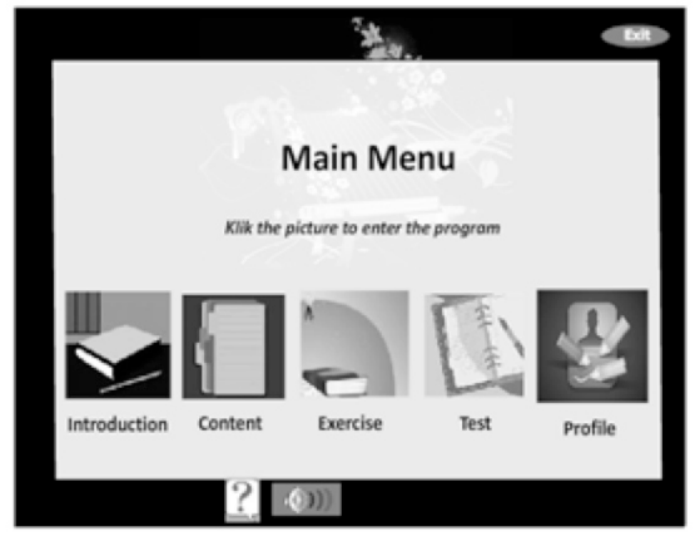

Picture 1. Instructional Multimedia CD

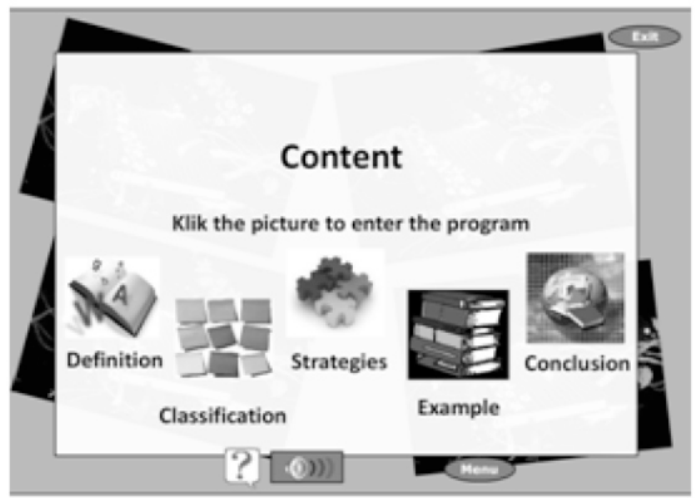

Picture 2. Instructional Multimedia CD

Picture 1 and 2 are instructional multimedia for English learning. This is a CD (Compact Disk) product, developed by using Macromedia Flash 8 (Gay, 2001: 1). The picture shows main menu screen that consist of five sections such as introduction, content, exercise, test and profile. These sections are arranged in sequence based on lesson plan or instructional design. This design is the 
application of behaviorist theory. In this theory, material are presented in sequence from the beginning (introduction) until the end (test or practice). This is usually called tutorial method.

Tutorial method is one of the methods in learning that uses tutor in a learning process in the form of person, computer or special print material. This method usually presents material from content, question and problem, students' responses, analysis and feedback (Newby et.al, 2000: 96). It is suggested to use this method to teach basic skills such as reading comprehension (Newby et.al, 2000: 97).

The advantages of using tutorial method are provide optimum individualized instruction, provide the highest degree of students participation, expands the number of "teacher" in the classroom by using students or computers as tutors and introduce new concept in a sequenced and interactive way (Newby et.al, 2000: 99). However, it is difficult to choose appropriate material for students in specific instructional condition. In some cases, it may be impractical since there is no specific material to support the content.

It is now the role of cognitive theory in determining appropriate content for specific learning. Analyze picture 3 below.

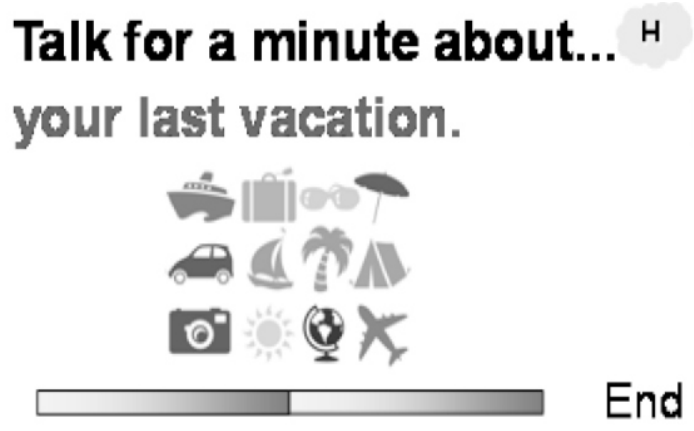

Picture 3. Power Point presentation 


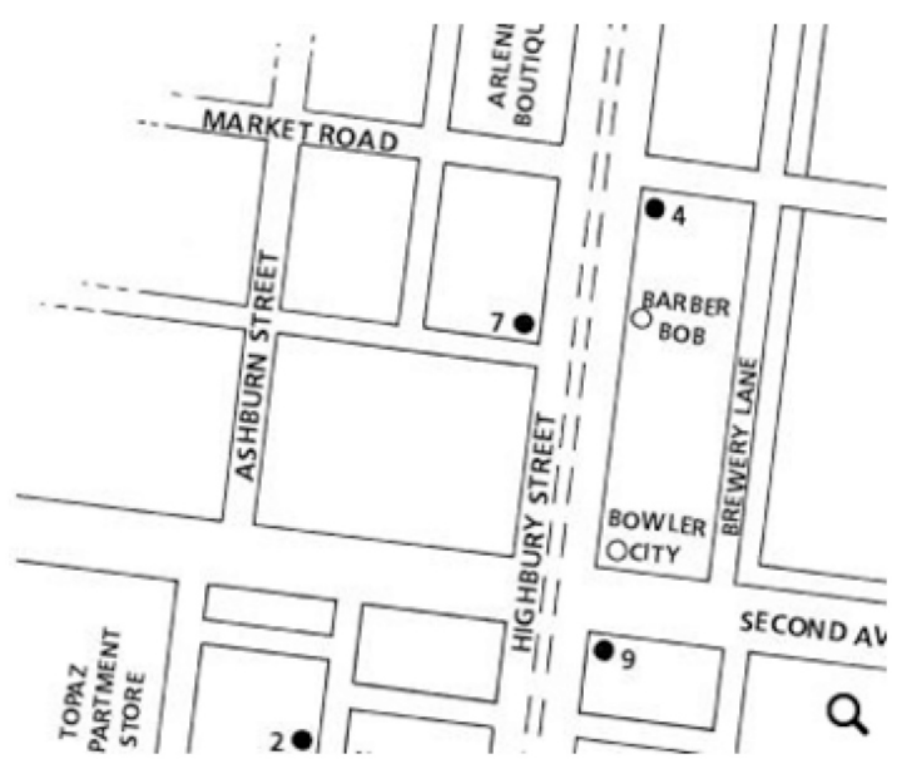

Picture 4 Picture of direction to practice speaking English

Picture 3 and 4 are power point presentation and picture about English Speaking activity. This material is for students in pre intermediate and intermediate level. The material uses simple sentences and general vocabulary. The images contain thematic pictures with simple speaking task. Based on the description, this material is assumed to be an appropriate method for beginner level in English learning. In some cases, this material can be used for Junior High School students. Choosing relevant content for students is the application of cognitive theory in multimedia product. It is supported by cognitive concept, described by Mayer (2007:54).

Mayer states that there are five stages in integrating cognitive theory in multimedia product: a) selected relevant words; b) selecting relevant images; c) organizing selected words; d) organizing selected images and e) integrating wordbased and images-based representation. Selecting content can be based on:

1. General characteristic: learners characteristics can be influenced by competency level, ethnic or culture. As the impact of these factors, an 
instructor may deal with heterogeneous groups which have different background, knowledge, expectation and motivation. Thus, superficial analysis of learner characteristics can provide helpful leads in selecting instructional methods and media.

2. Specific entry competencies: it is suggested that instructors must verify assumptions about entry competencies through informational means (such as in-class questioning or out-of-class interviews) or more formal means (such as testing with standardized or teacher-made tests). By analyzing specific entry competencies, an instructor can select appropriate methods and media.

3. Learning style: learning style refers to cluster of psychological traits that determine how an individual perceives, interacts with and responds emotionally to learning environments. There are four categories of learning styles such as perceptual preferences and strength (e.g. auditory, visual, tactile and kinesthetic), information processing habit (e.g. concrete sequential, concrete random, abstract sequential and abstract random), motivational factors (e.g. intrinsic motivators and extrinsic motivators) and psychological factors (gender, health and environment) (Smaldino, 2005: 49-52).

Look at another example below.

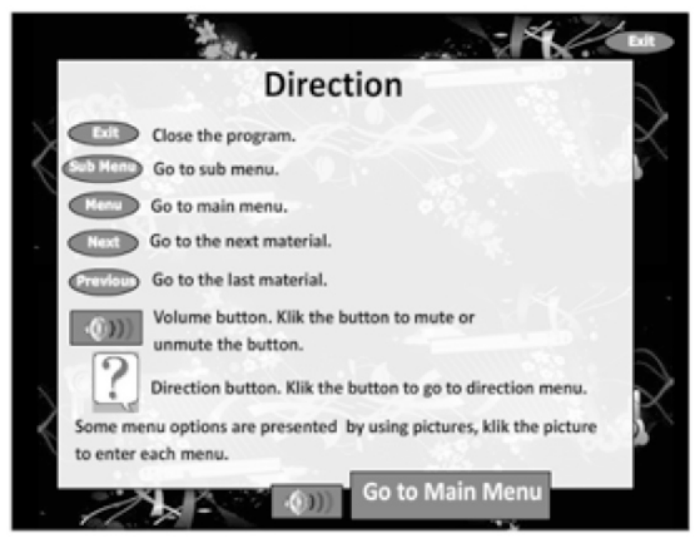

Picture 5. Direction for Self-learning 


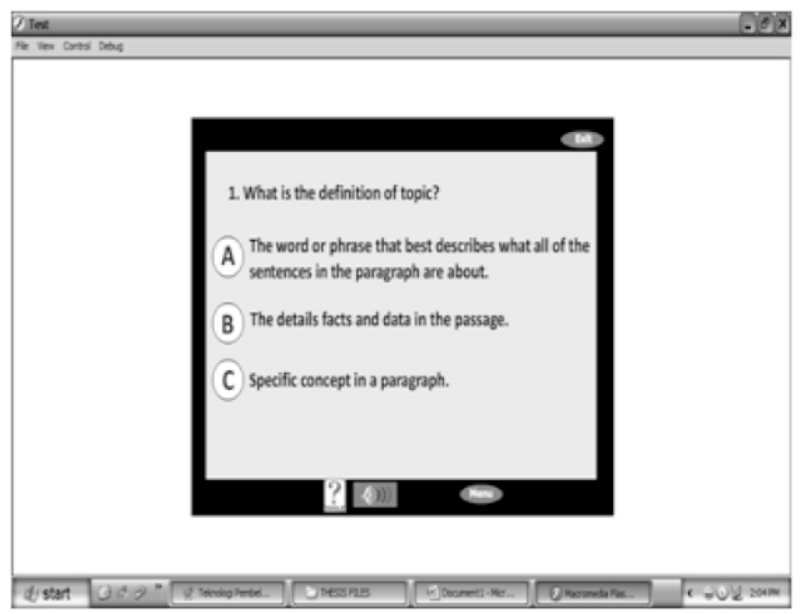

Picture 6. Practice test in instructional multimedia product

Picture 5 and 6 are similar to picture 1 and 2. They are also an instructional multimedia for English learning, developed by using Macromedia Flash 8. Picture 5 shows direction screen that consist of several symbols to enter the program. This direction is important because instructional multimedia in a CD is usually designed for self-learning, Students can explore the material without a tutor or a teacher. They also can study based on their own daily schedule. This media encourage students to build their own knowledge based on what they have learned. This is the application of constructivist theory. Based on Smaldino (2005: 6), constructivist perspective emphasize that learners create their own interpretations of the world of information. Students situate their learning experience within their own experience. Thus, the goal of instruction is to create a situation so that students can interpret information based on their understanding (Smaldino, 2005: 6).

Moreover, self-learning instructional multimedia is also the application of social-psychological perspective. This learning theory emphasizes on social skill such as team work or group discussion (Smaldino, 2005: 7). By using multimedia product without any teacher or tutor, students are encouraged to work with other students and to conduct group discussion among them to solve the problems and master the material. 


\section{CONCLUSIONAND SUGGESTION}

The integration of learning theories in multimedia development can enhance effective media in English learning. However, each theory has its advantage and disadvantage. Behaviorist theory can present material in sequence but this theory limit the learning process only in the changing of behavior. It does not consider students' mental and psychological condition. On the contrary, cognitive theory considers students' character as the main aspect in designing lesson. It gives positive impact for students because the material is designed based on their character, interest or demand. By using cognitive perspective, it is expected that learning objective can be reached effectively. Similar to cognitive theory, constructivist and social-psychological perspective also focuses students' character but these theories are not only discuss about students' condition and learning process but also knowledge building and social setting (e.g: classroom and society). A good combination of all learning theories might be a good solution to minimize the limitation.

The application of the learning theories are important to support the success of learning, especially English learning because English is not our vernacular so it needs specific strategies to master the skills such as Listening, Speaking, Reading and Writing. One of the popular media to support English learning at the present is instructional multimedia program by using computer. It is proven that instructional multimedia still can provide space for learning theories application by considering all aspects of multimedia based on students' need, for example: using relevant picture to visualize abstract concept. To conclude, all learning theories can complete each other in creating a well-planned instructional multimedia in computer program to support English learning.

\section{REFERENCES}

Aldrich, Clark. (2009). Learning Online With Games, Simulations and Virtual Worlds. Strategies for Online Instruction. San Fransisco: Jossey-Bass.

Busy Teacher Tim. 2012. Talk a minute. Power point presentation. http://busyteacher.org/ October $4^{\text {th }} 2012$.

Gay, J. 2001. The history of flash. http://www.adobe.com/macromedia/ events/john_gay/. November 8th 2011. 
Gebhard, J. 2005. Teaching English as a foreign or second language. Michigan: Michigan Press.

Mayer, R. E. 2007. Multi-media learning. New York: Cambridge University Press

Syah, Muhibbin. 2005. Islamic English. PT. Remaja Rosdakarya: Bandung.

Newby,et.al. 2000. Instructional technology for teaching and learning. Designing instruction, integrating computers, and using media. New Jersey: PrenticeHall, Inc.

Smaldino, et.al. 2005. Instructional Technology and Media for Learning. Ed. Ke-8. New Jersey: Person Merrill Prentice Hall.

Warsita, Bambang. 2008. Teknologi pembelajaran. Landasan dan aplikasinya. Jakarta: Rineka Cipta. 